\title{
Uptake and distribution of rare earth elements in rice seeds cultured in fertilizer solution of rare earth elements
}

\author{
Dongan Yuan, Xiao-quan Shan *, Qing Huai, Bei Wen, Xinru Zhu \\ Research Center for Eco-Environmental Sciences, Chinese Academy of Sciences, P.O. Box 2871, Beijing 100085, \\ People's Republic of China
}

Received 3 January 2000; accepted 3 April 2000

\begin{abstract}
The uptake behavior of rare earth elements (REEs) under pot conditions using deionized water and a REE fertilizer solution as the culture media as well as the distribution of REEs in rice proteins were studied. The uptake of REEs in rice seeds increased dramatically after a lag period of approximately three days. Roots can accumulate a much higher content of REEs than germs and the resting seeds. The REE content in each water-soluble (albumin) and salt-soluble (globulin) component of the rice seeds accounted for $5-8 \%$ and $4-6 \%$ of the total REEs, respectively. However, there are less than $1.5 \%$ of the total REEs were found in the alcohol-soluble (prolamin) and acetic acid-soluble (glutelin) components. The high performance liquid chromatography (HPLC) in the gel permeation and the reserved-phase were used to monitor changes in the molecular weight distribution changes of the soluble proteins of rice seeds during germination after having been cultured in the same solution for seven days. No changes occurred in the prolamin, while a slight change occurred in the albumin, globulin and glutelin. Fractionation of the albumin of rice seeds cultured in a REE fertilizer solution on the Sephadex G-100 column indicated that REEs, especially Ce, $\mathrm{La}, \mathrm{Pr}$ and $\mathrm{Nd}$, were associated mainly with biological compounds of a molecular weight between 10,000 and 12,000. (c) 2001 Elsevier Science Ltd. All rights reserved.
\end{abstract}

Keywords: Pot conditions; Germination; Storage proteins; High performance liquid chromatography; Inductively coupled plasma mass spectrometry

\section{Introduction}

Among the various plant protein sources, the seed plays an important role due to the presence of storage proteins. Albumin, globulin, prolamin and glutelin, all important components of the storage proteins of seeds, are classified by their solubility in various extractants (Diecket and Dieckert, 1985). Prior research (Mawal et al., 1987; Komatsu and Hirano, 1992) suggests that the major storage protein in the endosperm of rice is a type

\footnotetext{
${ }^{*}$ Corresponding author. Tel.: +86-10-62923560; fax: +86$10-62923563$.

E-mail address: xiaoquan@mail.rcees.ac.cn (X.-q. Shan).
}

of acidic and/or alkaline-soluble protein, glutelin, which accounts for $80 \%$ of the total protein content. The water-soluble protein, albumin, the salt-soluble protein, globulin and the alcohol-soluble protein, prolamin, are present in relatively low amounts in the rice endosperm and account for $0.5-7 \%, 2-8 \%$ and $1-5 \%$ of the total protein content in the endosperm, respectively. Although the protein content of rice $(9 \%)$ is lower than that of wheat $(12 \%)$, the rice protein has the highest quality among cereals in regards to digestibility value and protein efficiency. The amino acids, lysine and threonine, are rather rich in rice in comparison to other cereals (Gottschalk and Muller, 1983).

Due to the poor solubility of cereal proteins, heterogeneity and the tendency to polymerize, it is more 
difficult to purify and characterize the cereal proteins in comparison with other plant and animal proteins (Bietz, 1983). Numerous separation methods such as electrophoresis have been applied to purify these proteins over the past three decades (Tsugita et al., 1997). Research from the eighties suggested that high performance liquid chromatography (HPLC) is the most useful method because of its speed, sensitivity, resolution, reproducibility, quantification and ability to complement with other methods (Burnouf and Bietz, 1984; Huebner and Bietz, 1985).

More recent evidence (Brown et al., 1990) has demonstrated that rare earth elements (REEs) could stimulate the plant growth of cereals, vegetables, fruits and tea. In China, the use of REEs as fertilizer additives in some agriculture cases has been extensive. Numerous field experiments and pot studies suggest that REE fertilizer application cannot only increase the yield but also import many visual benefits to plants including a darker green foliage, an enhanced rate of development, a greater production of roots, as well as better fruit color in apples, oranges and watermelons. About $15-20 \%$ germination of the rice seed was enhanced after soaking the rice seeds with "Changle" fertilizer (Happiness forever) for $8 \mathrm{~h}$, which is a fertilizer containing REEs (Xu, 1995). Many questions remain unresolved, such as how REE fertilizer could increase the yield. This situation has encouraged many researchers to study the physiological effects of REE fertilizer on plants and animals.

In recent years many reports have appeared in literature on the absorption mechanism of REEs by plant roots and their growth response to REEs. Nagahashi et al. (1974) pointed out that Casparian strip acted as a barrier to the movement of lanthanum in the corn root. The rapid growth responses of oats treated with $\mathrm{La}^{3+}$, $\mathrm{Ca}^{2+}, \mathrm{K}^{+}$and $\mathrm{NH}_{4}^{+}$were measured and it was found that $\mathrm{La}$ did not behave like super calcium in its action upon the spontaneous growth response (Harmet, 1979). The series interactions of trivalent lanthanide cations with the thylakoid membrane surface of spinach chloroplasts verified that the added lanthanide cations were adsorbed onto the membrane surface to neutralize exposed segments of the membrane-embedded protein complex (Karukstis et al., 1995). Selective biosorption of lanthanide from an aqueous solution was studied and the lanthanide biosorption equilibrium obeyed the Brunaure-Emmett-Teller isotherm model, which indicated multilayer adsorption (Texier et al., 1999). It was verified that $\mathrm{Eu}(\mathrm{III})$ was adsorbed onto the surface of water hyacinth roots from water and was bound to the roots via carboxylate groups and the hydration of $\mathrm{Eu}(\mathrm{III})$ at the root surface (Kelly et al., 1999).

The aim of the present study was to investigate the uptake behavior of REEs by rice seeds cultured in a REE fertilizer solution. Various rice proteins, hemicellulose and crude fiber were separated, and the distribu- tion pattern of REEs in the protein and fiber was investigated.

\section{Materials and methods}

\subsection{Materials}

Mature seeds of rice were purchased from the Chinese Institute of Agricultural Science. Fertilizer called "Changle" was obtained from the Chinese Agronomic Application Center of Rare Earth Elements. Unless noted otherwise, all chemical reagents are of analytical grade or better. In the case of HPLC, the acetonitrile was of HPLC grade, trifluoroacetic acid (TFA) was obtained from Fluka (purity $>98 \%$ ) and all solvents were filtered with a $0.45 \mu \mathrm{m}$ membrane before use.

\subsection{Methods}

The rice seeds were polished and ground in order to pass through a 80-mesh sieve. The protein content of the polished rice was determined by the Kjeldhal method.

\subsection{The culture of rice seeds in the "Changle" fertilizer solution}

The mature rice seeds were sterilized for $60 \mathrm{~s}$ in $70 \%$ $\mathrm{v} / \mathrm{v}$ alcohol, at which point the seeds germinated in "Changle" fertilizer solution ( $\mathrm{pH}$ 6.0) consisting of $\mathrm{Y}$ $(15.1 \mathrm{ng} / \mathrm{ml}), \quad \mathrm{La}\left(6.9 \times 10^{3} \mathrm{ng} / \mathrm{ml}\right), \quad$ Ce $\left(1.37 \times 10^{4}\right.$ $\mathrm{ng} / \mathrm{ml}), \operatorname{Pr}\left(1.5 \times 10^{3} \mathrm{ng} / \mathrm{ml}\right), \mathrm{Nd}\left(4.8 \times 10^{3} \mathrm{ng} / \mathrm{ml}\right)$, Sm (14.7 ng/ml), Gd (297 ng/ml), Tb (15.7 ng/ml), Dy $(59.4 \mathrm{ng} / \mathrm{ml})$ and $\operatorname{Er}(24.4 \mathrm{ng} / \mathrm{ml})$. The concentrations of REEs in the polished rice seeds were determined each day. During the cultivation period, after every four days, the culture solution was changed with the same REE concentration of the fertilizer. After seven days, some of seeds were polished and then washed thoroughly with deionized water in preparation for protein separation.

After eight days of cultivation, the roots and germs grew so long that they could be separated from the seeds. The roots, germs and the remainder of the seeds were collected and the REE concentrations were determined.

\subsection{The separation of soluble proteins and insoluble components of the rice seeds}

The flour obtained from the polished rice was airdried at room temperature, and finally stored at $4{ }^{\circ} \mathrm{C}$ before use. The rice seed proteins were extracted and fractionated according to their solubility by a modified fractionation method described by Chen and Bushuk (1970). A schematic representation for the extraction procedures is summarized in Fig. 1. In addition to the 


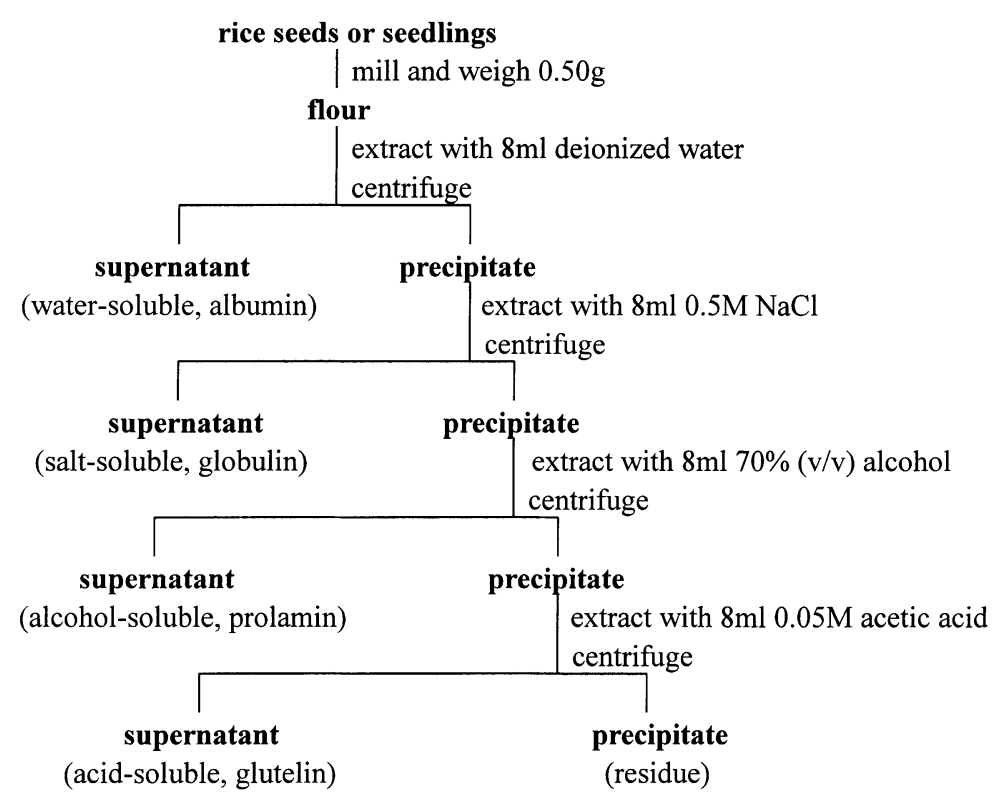

Fig. 1. A schematic diagram for separation of soluble proteins and residue of rice seeds.

insoluble component, the fractionation yields four soluble components: (a) water-soluble; (b) salt-soluble; (c) alcohol-soluble and (d) acetic acid-soluble. The above mentioned four soluble components refer to albumin, globulin, prolamin and glutenin, respectively. All extractions were made in an ice bath. The extracted components were stored in liquid nitrogen until further separation. The insoluble residue was further separated into several mixtures of starch and hemicellulose, protein and lipid, and crude fiber (Fig. 2).

\subsection{Characterization of albumin, globulin, prolamin and glutelin by HPLC}

The water-soluble, salt-soluble, alcohol-soluble and acetic acid-soluble components were first filtered with a $0.45 \mu \mathrm{m}$ membrane and later were further separated by HPLC. All HPLC chromatograms were obtained using the Waters 600 (Milford, MA, USA), and the proteins were separated with the TSK G3000SW column $(7.5 \times 300 \mathrm{~mm})$ and eluted with $0.1 \mathrm{M} \mathrm{Na}_{2} \mathrm{HPO}_{4-}$ $\mathrm{NaH}_{2} \mathrm{PO}_{4}$ of buffer solution ( $\mathrm{pH}$ 7.0) at a flow rate of 1 $\mathrm{ml} / \mathrm{min}$. The absorbance of the eluted proteins was measured at $280 \mathrm{~nm}$. All marker proteins, purchased from Sigma (St. Louis, MO, USA), were used directly. Prolamin was also separated by RP-HPLC with a Vydac C18 column $(4.6 \times 150 \mathrm{~mm})$. Elution was carried out with a gradient from $40 \%$ to $55 \%$ B during a $30 \mathrm{~min}$ period. The solvents $\mathrm{A}$ and $\mathrm{B}$ were deionized water $+0.1 \%$ TFA and $90 \%$ acetonitrile $+0.1 \%$ TFA, respectively.
The water-soluble component of the seeds exposed in the REE fertilizer solution was applied to a Sephadex G100 column $(2.6 \times 60 \mathrm{~cm})$. Elution was carried out with $0.05 \mathrm{M}$ Tris- $\mathrm{HCl}(\mathrm{pH} 7.5)$ at a flow rate of $1 \mathrm{ml} / \mathrm{min}$.

\subsection{Determination of REES}

The concentrations of REEs were determined by inductively coupled plasma mass spectrometry (ICP-MS) (Plasma Quad III). The seeds were collected, rinsed with deionized water, dried, weighted and analyzed after decomposition with $\mathrm{HNO}_{3} / \mathrm{HClO}_{4} / \mathrm{HF}$ (Zhang and Shan, 1997). The residues were dried, weighed and analyzed with the same method and the four seed protein components were analyzed directly after passing through a $0.45 \mu \mathrm{m}$ membrane. A solution of ${ }^{115} \mathrm{In}$ at $10 \mathrm{ng} / \mathrm{ml}$ in $2 \%$ $\mathrm{HNO}_{3}$ was also used as an internal standard to compensate for matrix suppression and signal drifts during analysis.

\section{Results and discussion}

\subsection{Uptake behavior of REE from the REE fertilizer solution}

The relationship between the REE concentration in the rice seeds or seedlings and the cultivation time was studied. In the "Changle" fertilizer solution, the main REEs are $\mathrm{La}(25.3 \%), \mathrm{Ce}(50.2 \%), \operatorname{Pr}(5.5 \%)$ and $\mathrm{Nd}$ $(17.6 \%)$. Due to quite similar uptake behavior of REEs 


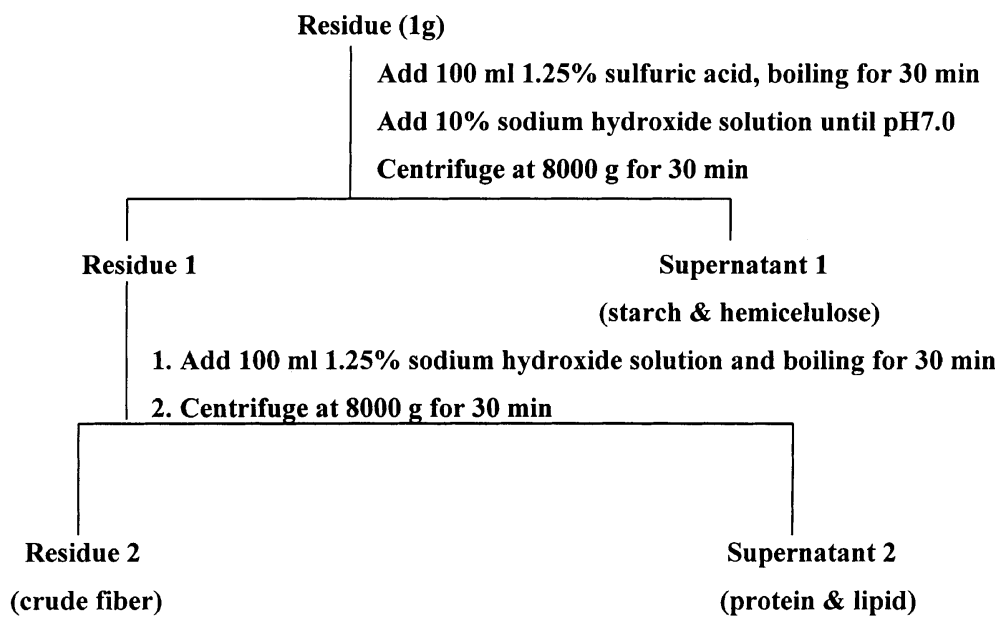

Fig. 2. A schematic diagram for separation of insoluble residue.

in rice seeds a typical uptake behavior of $\mathrm{Ce}$ is shown in Fig. 3. The culture period can be roughly divided into several stages: stage 1 , the water absorption process was expected to occur from day 1 to day 2, and the concentration of $\mathrm{Ce}$ in the rice seeds remained unchanged. Stage 2, germination may occur, although there was no visible evidence of sprouting from day 3 to day 4 . This stage may be expressed as the incipient sprouting. The concentration of $\mathrm{Ce}$ in the rice seeds increased, partic- ularly during day 4, although the reason is unclear. Stage 3, roots and germs appeared on days 5 and 6, respectively. From 5th day on the concentration of $\mathrm{Ce}$ in the rice seeds and/or seedlings increased gradually with an increase in cultivation time. In order to explain the reason why the concentration of $\mathrm{Ce}$ increased with cultivation time the rice seedling were separated into the root, germ and endosperm components after a cultivation time of 8 days, at which point the concentrations of

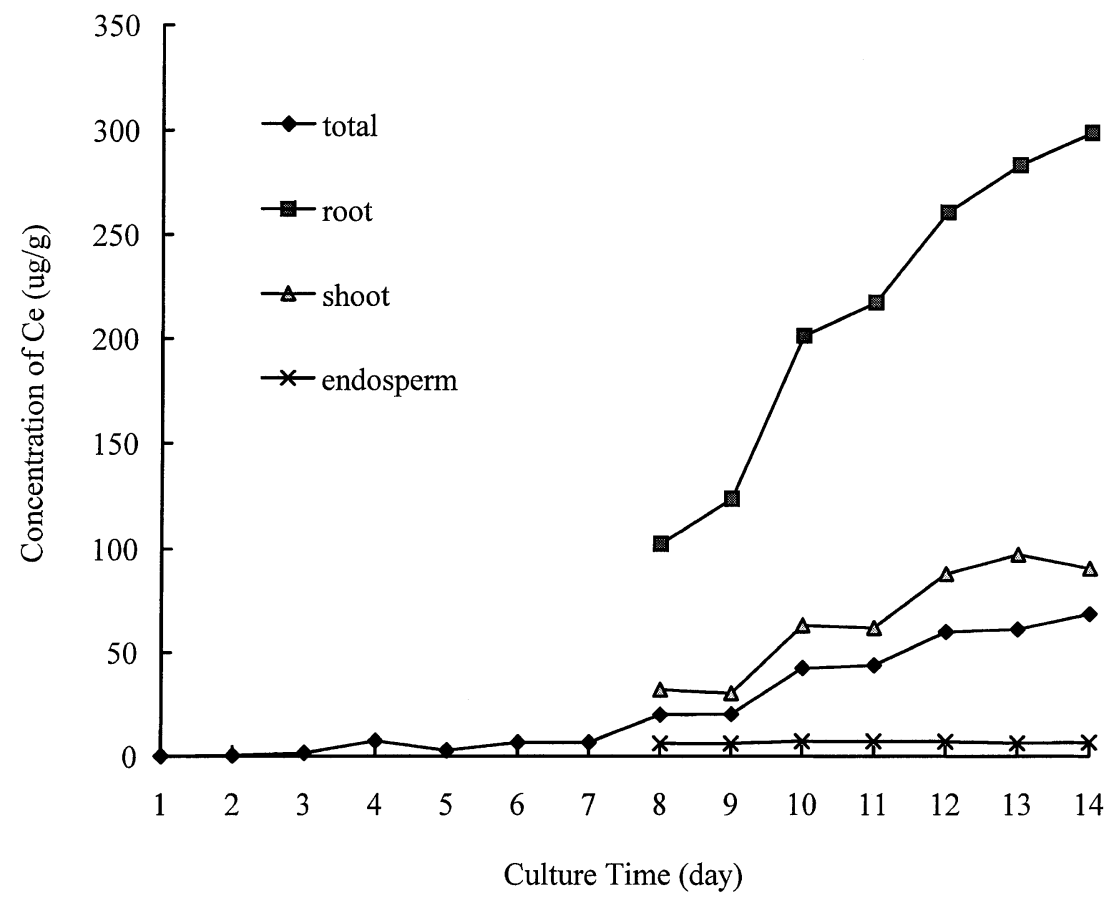

Fig. 3. Uptake of $\mathrm{Ce}$ in the rice seed, root, germ and endosperm. 
Ce were determined. Fig. 3 clearly shows a greater accumulation of $\mathrm{Ce}$ in the roots. It was also verified that the germs accumulated much less $\mathrm{Ce}$ and remained virtually unchanged in the endosperm. No significant increase was observed from day 8 to day 14. It is generally recognized that the root is the most important organ not only for absorbing water and mineral nutrients for plants but also for synthesizing organic substances. The root is the basis for plant growth and development. Developed roots have a strong adsorptivity and encourage plant organs which are effectively growing well above ground to attain high productivity. Many researchers (Harmet, 1979; Hanzely and Harmet, 1982; Guo et al., 1988; Gao, 1997) reported that REEs could stimulate the growth and development of plants, especially in plant roots. The above results demonstrated that the roots of rice could accumulate a much higher REE concentration than in the germs and the resting seeds, which is consistent with the literature ( $\mathrm{Li}$ et al., 1998). From our results we suggested that at least one reason for the REE concentration difference between the root and stem could be attributed to the absorption ability. Although REEs could stimulate the root growth and greater root production, the transport speed from root to the above ground organs is relatively slow. For example, about 99\% REEs remained in the roots after the wheat and peanut uptake of REEs. Although the transport ability of the rice root is much higher, about $15-20 \%$ of the REEs were transported to the above ground organs (Oparka and Gates, 1981). This is the another probable reason why a much lower concentration of REEs was found in the germs.

\subsection{Distribution of REEs in the soluble proteins and the insoluble components of rice seeds}

Various soluble proteins and the insoluble components of rice seeds were separated (Fig. 1) and the REEs concentrations in each component were determined. The results are schematically shown in Fig. 4. Due to the same considerations as the uptake behavior of REEs from the cultivation solution, only $\mathrm{Ce}$ is elucidated. As can be seen quite clearly from Fig. 4 there were about 5 $8 \%$ and $4-6 \%$ of the total Ce in each of the water-soluble and salt-soluble proteins, and only about $1 \%$ of total $\mathrm{Ce}$ was detected in the alcohol-soluble protein. These REEs may play an important role in participating in the life activity of plants, such as affecting the nucleic acids and proteins within the cell and nucleus, stimulating root elongation and cell division, and other biological functions.

It should also be pointed out that more than $80 \%$ of total REEs remained in the insoluble component. In order to have a clearer understanding of the distribution of REEs in the residue, several portions of the residue, obtained during the final stage for the soluble protein separation, were combined and separated into three mixtures: starch and hemicellulose, protein and lipid, and crude fiber (Fig. 2). The concentration of REEs in each mixture was determined, and the results are

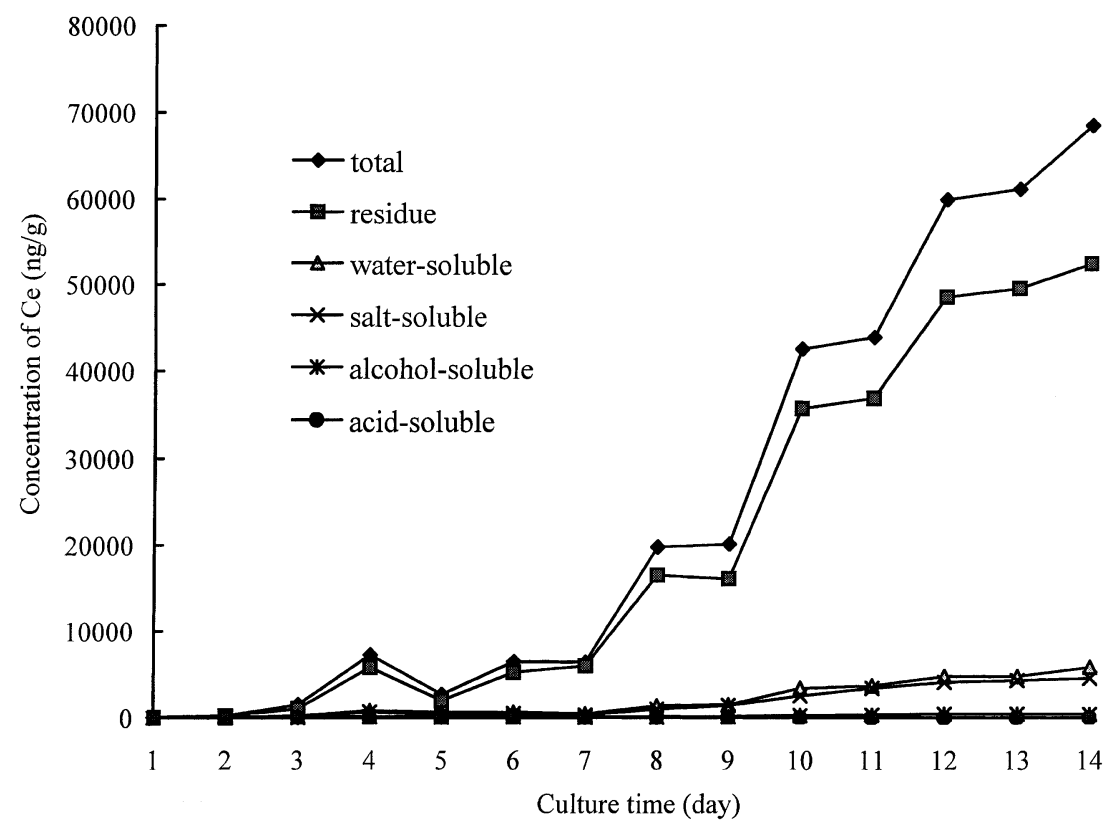

Fig. 4. Distribution of $\mathrm{Ce}$ in soluble protein and residue. 
Table 1

The average concentration of REEs in different components of residue (ng/g) $(n=5)$

\begin{tabular}{lrrrr}
\hline & \multicolumn{1}{c}{ Total } & Starch \& hemicellulose & Protein \& lipid & Crude fiber \\
\hline $\mathrm{Y}$ & 30.63 & 20.37 & 0.46 & 10.29 \\
$\mathrm{La}$ & 4886.52 & 4828.92 & 23.76 & 38.22 \\
$\mathrm{Ce}$ & 6398.23 & 6128.81 & 146.46 & 123.50 \\
$\mathrm{Pr}$ & 762.59 & 734.53 & 13.94 & 8.40 \\
$\mathrm{Nd}$ & 3299.09 & 3136.29 & 14.74 & 24.35 \\
$\mathrm{Sm}$ & 13.76 & 12.16 & 0.39 & 2.20 \\
$\mathrm{Eu}$ & 2.29 & 1.29 & 0.29 & 1.04 \\
$\mathrm{Gd}$ & 84.63 & 80.16 & 0.15 & 2.63 \\
$\mathrm{~Tb}$ & 6.10 & 20.47 & 0.19 & 0.43 \\
$\mathrm{Dy}$ & 23.06 & 1.69 & 0.31 & 2.29 \\
$\mathrm{Ho}$ & 2.24 & 5.11 & 0.19 & 0.52 \\
$\mathrm{Er}$ & 7.18 & 1.18 & 0.35 & 0.30 \\
$\mathrm{Tm}$ & 1.50 & 1.65 & 0.40 & 0.27 \\
$\mathrm{Yb}$ & 3.03 & 1.20 & 0.07 & 1.50 \\
$\mathrm{Lu}$ & 1.89 & & & 0.59 \\
\hline
\end{tabular}

summarized in Table 1. The predominant REEs of more than $95 \%$ of total, especially $\mathrm{La}, \mathrm{Ce}, \mathrm{Pr}$ and $\mathrm{Nd}$, were found to be in the mixture of starch and hemicellulose. As far as the other REEs were concerned, the ratio of REEs concentration in the starch and hemicellulose to the total REEs in the residue, ranged from 56\% to $94 \%$. These REEs may be deposited in cellulosic and interfibrillar regions of the cell wall.

\subsection{Change in molecular weight distribution of the soluble protein upon cultivation}

A size exclusion HPLC (SE-HPLC) can rapidly determine the molecular weight distribution of soluble proteins in sound and cultured rice seeds. The soluble proteins obtained by the Chen and Bushuk method were further applied to SE-HPLC. All chromatograms for the rice seeds were cultured in the deionized water and REE fertilizer solution for seven days, and are shown in Figs. 5-7 together with the chromatograms for the sound rice seeds.

For the water-soluble protein, albumin, the chromatograms can be divided into four molecular weight groups (Fig. 5). High molecular weight proteins, of approximately 230,000 , were eluted at $6 \mathrm{~min}$, intermediate molecular weight protein of 65,000 at $9 \mathrm{~min}$, low molecular weight protein of 10,000-12,000 between 13 and $14 \mathrm{~min}$, lower molecular weight peptides and amino acids, of less than 7,000, were eluted longer than $15 \mathrm{~min}$.

Changes in the molecular weight distribution of albumin in the sound rice seeds, and rice seeds cultured in the deionized water and the REE fertilizer solution, are quite obvious. There are four observable molecular weight components in the sound rice seeds (Fig. 5(a)). A very small, high molecular weight component was detected in the rice seeds cultured in the water (Fig. 5(b)). It must be noted that the major observable change in the molecular weight distribution was a very small peak of high molecular weight protein, of 230,000, and the high molecular weight species, of 65,000 , disappeared completely for rice seeds cultured in the deionized water. No high molecular weight protein species remained if the rice seeds were cultured in the REE fertilizer solution for seven days. In contrast, the low molecular weight components of 7,000, 5,000 and 4,200 increased slightly. The increase in soluble amino nitrogen upon germination is due predominantly to amino acids. Such amino acids are formed by the nonspecific carboxypeptidases and the two amino peptides present in the endosperm. This was in agreement with the literature (Preston et al., 1978).

For the salt-soluble protein, globulin, the chromatograms of the high molecular weight groups are quite similar regardless of whether they are for sound rice seeds, for rice seeds cultured in water, or those in the REE fertilizer solution. If compared with the chromatograms of low molecular weight groups of about 10,000 , it is evident that a peak of 15,000 appeared for rice seeds cultured in the deionized water and the REE fertilizer solution (Fig. 6).

It was evident that there was no change in the molecular weight distribution for the alcohol-soluble protein, prolamin, no matter how the rice seeds were cultured in the deionized water or the REE fertilizer solution (not shown). It was also proved with RP-HPLC (not shown). Prolamin is present in relatively low amounts in the rice, endosperm, and accounts for $1-5 \%$ the total protein content (Gottschalk and Muller, 1983). At the same time, the content of REEs in prolamin is about $0.5 \%$ of the total REEs in seeds. Therefore, we suggested that rice seeds exposed to the REE fertilizer solution for prolonged times could not influence constitution of prolamin during germination.

It can be seen clearly from Fig. 7 that the high molecular weight protein of approximately 265,000 for 

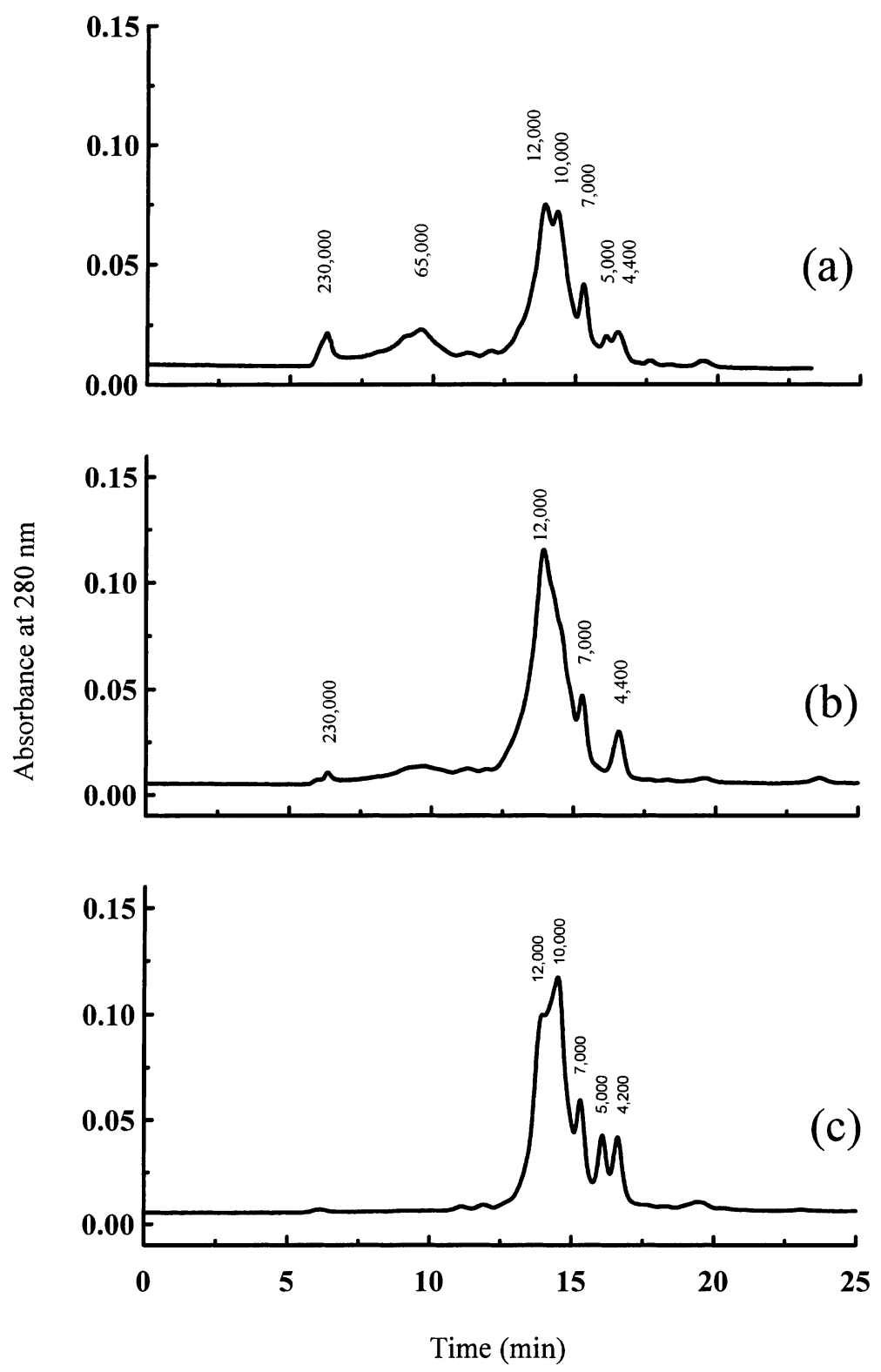

Fig. 5. Chromatogram of water-soluble proteins in rice seeds: (a) polished sound rice seeds; (b) polished rice seeds after seven day germination in deionized water; (c) polished rice seeds after seven day germination in REE fertilizer solution. Gel-permeation chromatography on a TSK G3000SW column $(7.5 \times 300 \mathrm{~mm})$ was used. The column was equilibrated with $0.1 \mathrm{M} \mathrm{Na}_{2} \mathrm{HPO}_{4}-\mathrm{NaH}_{2} \mathrm{PO}_{4}$ buffer, $\mathrm{pH} 7.0$ at the flow rate of $1 \mathrm{ml} / \mathrm{min}$. The proteins used as standards were $\beta$-galactosidase (MW. 116,000), bovine serum albumin (MW. 66,000), egg albumin (MW. 45,000), pepsin (MW. 34,700), trypsinogen (MW. 24,000) and lysozyme (MW. 14,000).

sound rice seeds, disappeared when the rice seeds were cultured in deionized water or a REE fertilizer solution. The chromatograms were quite similar for proteins of low molecular weight, the peptides and amino acids of sound rice seeds and rice seeds germinated in deionized water, or the REE fertilizer solution. But a new species of 25,600 occurred in the front shoulder in Fig. 7(b) and (c) if compared with (a).
Although the mechanisms controlling the mobilization of storage proteins in germinating cereals are still not clearly understood, our results are very similar to other reports concerning wheat and other grains (Montembault et al., 1983; Kruger, 1984; Kruger and Marchylo, 1985). These results suggested that during early the germination period (up to two or three days), proteolytic enzymes such as endopeptidases, 

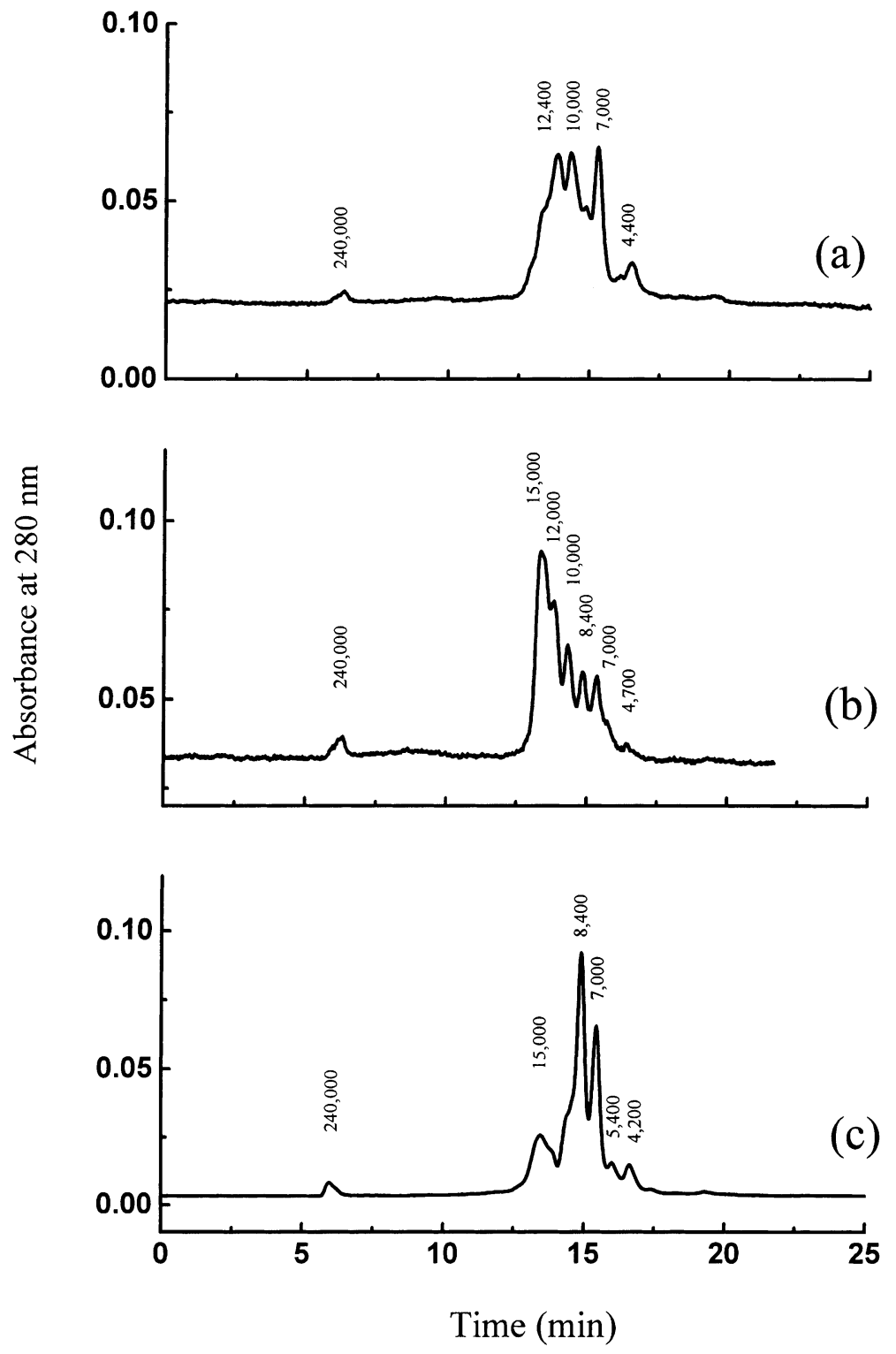

Fig. 6. Chromatogram of salt-soluble proteins in rice seeds: (a) polished sound rice seeds; (b) polished rice seeds after seven day germination in deionized water; (c) polished rice seeds after seven day germination in REE fertilizer solution. The other conditions are the same as Fig. 5.

carboxypeptidases and aminopeptidases have little effect on the mobilization of the endosperm storage reserves. From two to three days on, the enzyme abilities of endopeptidases and carboxypeptidases increase rapidly, storage protein hydrolysis increases correspondingly, and the major products formed are amino acids and peptides. In addition, Lorenz (1980) reported that the sprouting of grains can cause a series of property changes including an increase in enzyme activity and total protein; changes in amino acid composition; a loss of total dry matter; a decrease in starch and sugars; a slight increase in crude fat and crude fiber etc.

From (b) and (c) in Figs. 5-7, during germination with the REE fertilizer solution, protein components of albumin, globulin and glutelin are similar, but the relative ratios have some differences between proteins of various molecular weights. For example, compared with Fig. 7(b), the peaks of 10,000 and 4,700 in Fig. 7(c) were higher. 

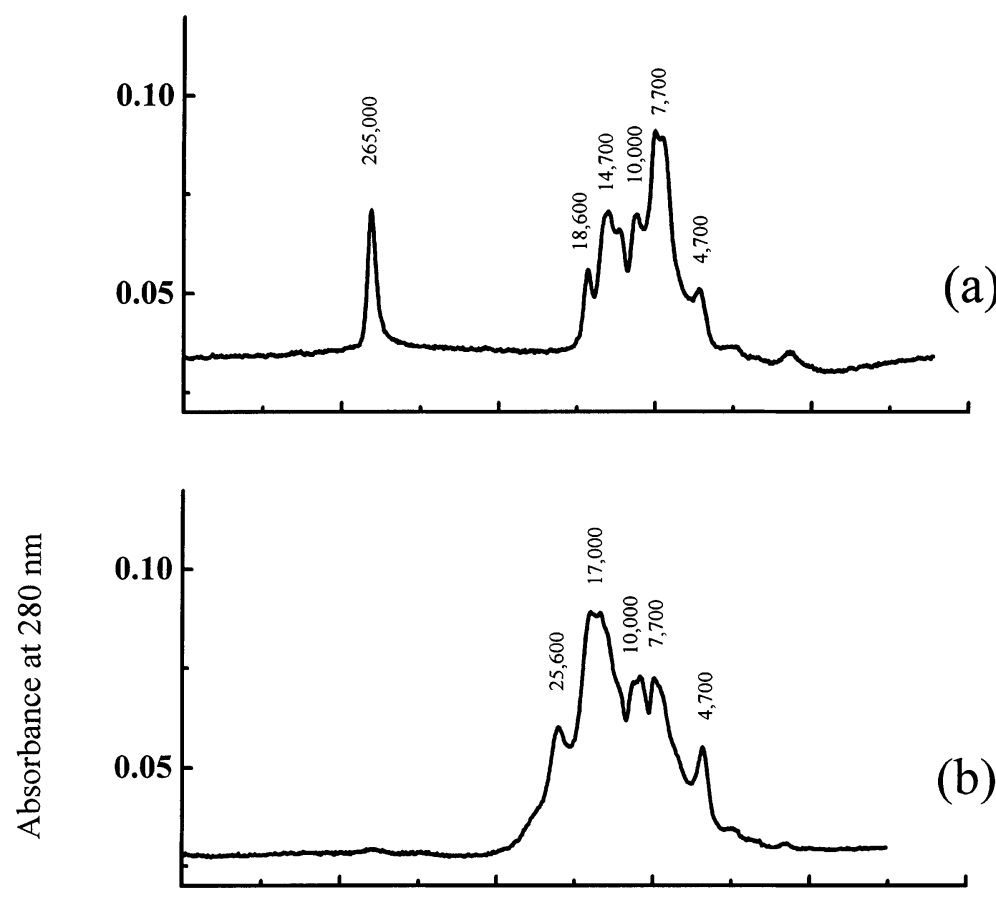

(b)

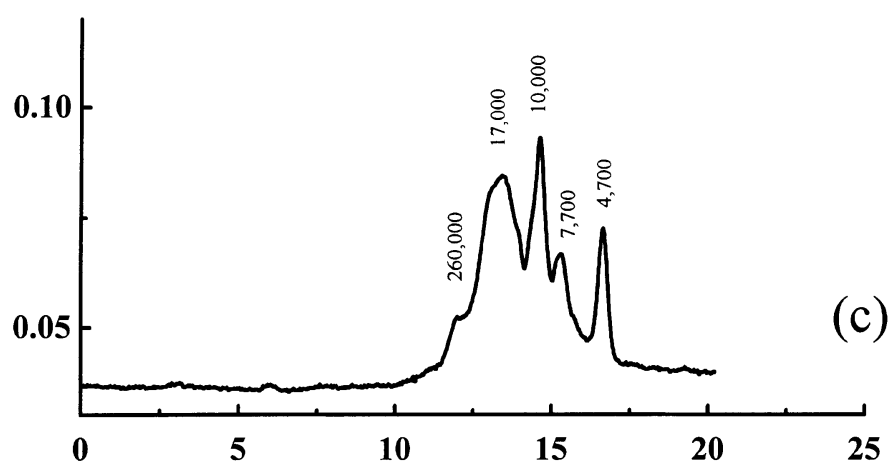

Time (min)

Fig. 7. Chromatogram of acetic acid soluble proteins in rice seeds: (a) polished sound rice seeds; (b) polished rice seeds after seven day germination in deionized water; (c) polished rice seeds after seven day germination in REE fertilizer solution. The other conditions are the same as Fig. 5.

\subsection{REE-bound protein}

In order to examine whether REEs bound with rice protein, Albumin was chosen as a representative and was applied to a Sephadex G-100 column $(2.6 \times 70 \mathrm{~cm})$. The results are schematically shown in Fig. 8. It was evident that there was a prominent band of UV absorption at $280 \mathrm{~nm}$, corresponding to a molecular weight of approximately 10,000-12,000. This compound binds about $50 \% \mathrm{Ce}, 13 \% \mathrm{La}, 20 \% \mathrm{Pr}$ and $20 \% \mathrm{Nd}$ of total amount in the whole water-soluble component.
Although there were only a few reports in the literature about plant REEs-binding protein, Zhong and Min (1994) separated REE-binding lipo-polysaccharide from natural tea. From the natural plant fern, Dicranopters dichotoma, Guo et al. (1996) separated REEbinding proteins with molecular weights of 14,100 and 38,700 . Generally, the present study demonstrated the binding of REEs to the plant proteins although further purification and characterization of proteins are required. Nevertheless, the present study is a valid step which forwards the understanding of the uptake be- 


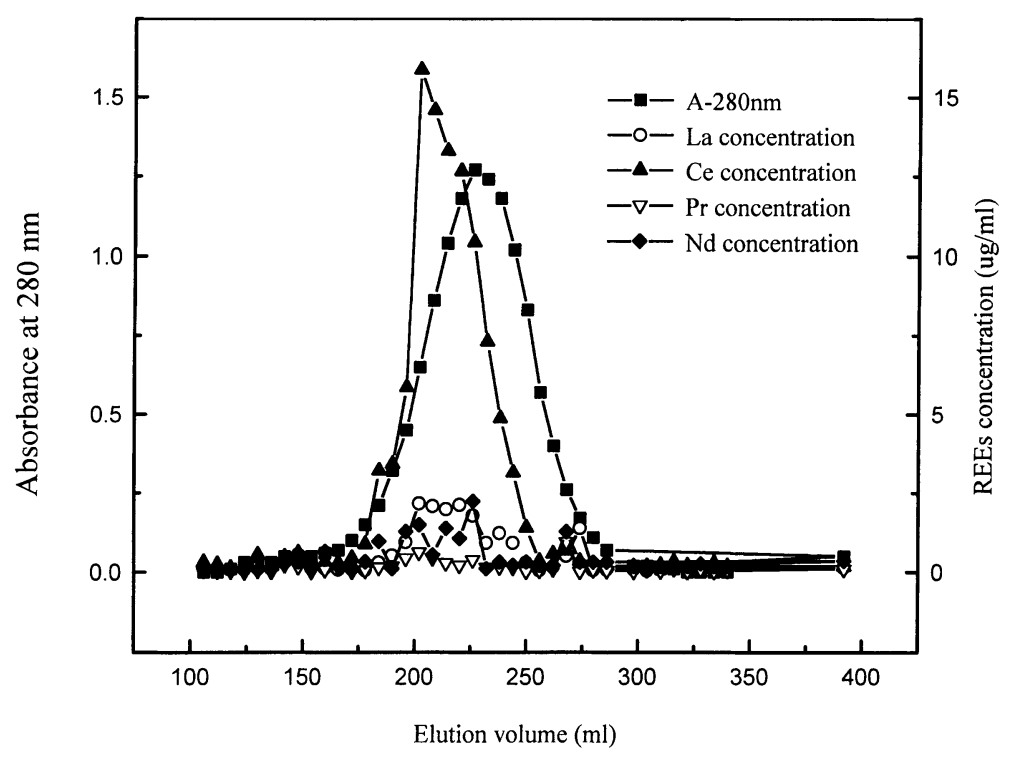

Fig. 8. REEs-binding albumin with gel permeation Sephadex G-100 column $(2.6 \times 70 \mathrm{~cm})$.

havior of REEs from solution or/and soil, as well as the distribution mechanism of REEs in plants

\section{Acknowledgements}

This work was supported by the National Natural Science Foundation of China and the Chinese Academy of Sciences, and the Research Center for Eco-Environmental Sciences.

\section{References}

Bietz, J.A., 1983. Separation of cereal proteins by reversedphase high-performance liquid chromatography. J. Chromatogr. 255, 219-238.

Brown, P.H., Rathjen, A.H., Graham, R.D., Tribe, D.E., 1990. Rare earth elements in biological systems. In: Gschneidner, K.A.J., Eyring, L., (Eds.), Handbook on the Physics and Chemistry of Rare Earth. Elsevier, Amsterdam, pp. 423-452.

Burnouf, T., Bietz, J., 1984. Reserved-phase high-performance liquid chromatography of reduced glutenin, a disulfidebonded protein of wheat endosperm. J. Chromatogr. 299, 185-199.

Chen, C.H., Bushuk, W., 1970. Nature of proteins in triticale and its parental species 1. Solubility characteristic and amino acid composition of endosperm proteins. Can. J. Plant Sci. 50, 9-14.

Diecket, K.W., Dieckert, M.C., 1985. Seed storage proteins. In: Altschul, A.M., Wilcke, H.L. (Eds.), New Protein Foods. Academic Press, London, pp. 1-25.

Gao, X.X., 1997. Rare Earth Elements Applied in Agriculture and Electroanalytical Chemistry. Peking University Press, Beijing, pp. 30-36.
Gottschalk, W., Muller, H.P., 1983. Seed Protein. Dr. W. Junk Publisher, pp. 225-244.

Guo, F.Q., Wang, Y.Q., Sun, J.X., Chen, H.M., 1996. Preliminary study on rare earth bound proteins in natural plant fern dicranopteris dichotoma. J. Radioanal. Nucl. Chem. 209, 91-99.

Guo, B.S., Zhu, W.M., Xong, B.K., 1988. Rare Earth Elements in Agriculture. China Agriculture Science and Technology Press, Beijing, pp. 55-60.

Hanzely, L., Harmet, K.H., 1982. Effect of lanthanum on cell wall elongation in Avena coleoptile segments: physiological and ultrastructural studies. Z. Pflanzenphysiol. 107, 223230.

Harmet, K.H., 1979. Rapid growth responses of Avena Coleoptile segments to lanthanum and other cations. Plant Physiol. 64, 1094-1098.

Huebner, F.R., Bietz, J.A., 1985. Detection of quality differences among wheat by high-performance liquid chromatography. J. Chromatogr. 327, 333-342.

Karukstis, K.K., Kao, M.Y., Savin, D.A., Bittker, R.A., Kaphengst, K.J., Emetarom, C.M., Naito, N.Y., Takamoto, D.Y., 1995. Spectral studies of lanthanide interactions with membrane surfaces. J. Phys. Chem. 99, 4339-4346.

Kelly, C., Mielke, R.E., Dimaquibo, D., Curtis, A.J., Dewitt, J.G., 1999. Adsorption of $\mathrm{Eu}(\mathrm{III})$ onto roots of water hyacinth. Environ. Sci. Technol. 33, 1439-1443.

Komatsu, S., Hirano, H., 1992. Rice seed globulin: a protein similar to wheat seed glutelin. Phytochem. 31, 3455-3459.

Kruger, J.E., 1984. Rapid analysis of changes in the molecular weight distribution of buffer-soluble proteins during germination of wheat. Cereal Chem. 61, 205-208.

Kruger, J.E., Marchylo, B.A., 1985. Examination of the mobilization of storage proteins of wheat kernels during germination by high-performance reversed-phase and gel permeation chromatography. Cereal Chem. 62, 1-5. 
Li, F.L., Shan, X.Q., Zhang, T.H., Zhang, S.Z., 1998. Evaluation of plant availability of rare earth elements in soils by chemical fractionation and multiple regression analysis. Environ. Pollut. 102, 269-277.

Lorenz, K., 1980. Cereal sprouts: composition, nutritive value, food applications. Crit. Rev. Food Sci. Nutr. 13, 353-385.

Mawal, Y.R., Mawal, M.R., Ranjekar, P.K., 1987. Biochemical and immunological characterization of rice albumin. Bioscience Rep. 7, 1-9.

Montembault, A., Autran, J.C., Joudrier, P., 1983. Varietal identification of barley and malt. J. Inst. Brew. 89, 299-306.

Nagahashi, G., Thomson, W.W., Leonard, R.T., 1974. The Casparian strip as a barrier to the movement of lanthanum in corn roots. Science 183, 670-671.

Oparka, K.J., Gates, P., 1981. Transport of assimilates in the developing caryopsis of rice (Oryza sative L.): the pathways of water and assimilated carbon. Planta 152, 388-396.
Preston, K.R., Dexter, J.E., Kruge, J.E., 1978. Relationship of exo- and endoproteolytic activity to storage protein hydrolysis in germinating durum and hard red spring wheat. Cereal Chem. 55, 877-882.

Texier, A.C., Andres, Y., Cloirec, P.L., 1999. Selective biosorption of lanthanide ( $\mathrm{La}, \mathrm{Eu}, \mathrm{Yb})$ ions by Pseudomonas aeruginosa. Environ. Sci. Technol. 33, 489-495.

Tsugita, A., Kawakawi, T., Uchiyama, Y., Kamo, M., Miyatake, N., Nozu, Y., 1997. Separation and characterization of rice protein. Electrophoresis 15, 708-720.

Xu, G.X., 1995. Rare Earths, second ed., vol. 3. Metallurgical Industry Press, Beijing, pp. 563-572.

Zhang, S.Z., Shan, X.Q., 1997. The determination of rare earth elements in soil by inductively coupled plasma mass spectrometry. At. Spectros. 18, 140-144.

Zhong, S.L., Min, W.Z, 1994. Separation of a REE-binding lipo-polysaccharide in tea. Chinese Sci. Bull. 39, 863. 